\title{
Imagining the beauty and hope of a colourful phoenix rising from the ashes of Marikana and service delivery protests: A postfoundational practical theological calling
}

\author{
Author: \\ Johann-Albrecht Meylahn ${ }^{1}$

\section{Affiliation:} \\ ${ }^{1}$ Department Practical \\ Theology, University of \\ Pretoria, South Africa \\ Note: \\ This article was initially \\ a presentation to the \\ Symposium Social Cohesion, \\ August 07-08, 2013, directed \\ by Prof. Dr Johann-Albrecht \\ Meylahn, Department of \\ Practical Theology, Faculty \\ of Theology, University of \\ Pretoria, Pretoria, \\ South Africa
}

Correspondence to:

Johann-Albrecht Meylahn

Email:

johann.meylahn@up.ac.za

Postal address:

Private Bag X20, Hatfield

0028, South Africa

\section{Dates:}

Received: 27 Jan. 2014

Accepted: 14 Mar. 2014

Published: 15 Aug. 2014

How to cite this article:

Meylahn, J-A., 2014,

'Imagining the beauty

and hope of a colourful

phoenix rising from the

ashes of Marikana and

service delivery protests: A

postfoundational practical

theological calling', HTS

Teologiese Studies/

Theological Studies 70(1),

Art. \#2616, 6 pages. http://

dx.doi.org/10.4102/hts.

v70i1.2616

\section{Copyright:}

(c) 2014. The Authors.

Licensee: AOSIS

OpenJournals. This work

is licensed under the

Creative Commons

Attribution License.

\section{Read online:}

The last few years the young democratic South Africa's history has been characterised by service delivery protests and industrial action which is becoming increasingly violent as epitomised by Marikana. Is the violence that accompanies industrial action and service delivery protests emblematic of a powerless frustration and a violent revulsion at the thought that there will be no change? For 18 years, hope was placed in the idea of liberation which would open the doors to a brighter future for the majority, yet all that remains of that noble dream lies in the ashes of current events that populate the newspaper headlines of the major South African newspapers. What role can Practical Theology play in this context? What is the calling of Practical Theology, and specifically postfoundational narrative theology? These are the questions this article will seek to answer, by proposing that a narrative approach can listen to the untold stories and thus the colourful phoenix can rise from the ashes.

In the last few years the young South African democracy has experienced certain historical events that have caught the attention of all major - local and numerous international - newspapers. These events have become themes of much discussed and debated public discourses and have changed the international image of South Africa. One event that stands out for various reasons, but probably because of its publicity, is the incidences leading up to what has been given the name Marikana, where Marikana is no longer just the name of a place, but has become the name of an event.

Names are given to events and things so as to identify them, and by identifying them getting a grip or a hold on them, so much so that one can say: 'that is Marikana'. But is it possible to name an event? To say: 'This or that is Marikana'? One can name a thing, an object, but how does one name a historical event? Yet, the history books are filled with names of events, for example in the history of South Africa: the Battle of Blood River (16 December 1838) or Sharpeville (21 March 1960). By giving events names, one conjures up the idea that everyone knows what one is referring to. But, what exactly do such names refer to? They refer to a series of incidences that have culminated into an event that carries certain historical weight. This means that within the narrative of a country these events are determining for what happened afterwards, or for what is expected to happen afterwards. In other words, after such events things can never be the same again. Events are emplotted within a narrative wherein they are seen as the consequence or culmination of certain incidences, and they are seen as determinants for future incidences and events. An event becomes an identifiable event by being placed within a causal chain in the form of being emplotted within a narrative (see Ricoeur 1984).

Is Marikana, as well as the other events like Sharpeville or the Battle of Blood River, an observable and thus objective occurrence or happening, where it is possible to give a specific determined or causal explanation of what actually happened? There are many who have attempted to give Marikana such a causal explanation, but is it possible to give such socialhistorical events singular conclusive causal explanations? Paul Ricoeur argues that we cannot, because events need to be seen and therefore treated as texts. If they are seen as texts, they can certainly be interpreted and indeed be explained, but explanation and interpretation is never final, and therefore there will be various and conflicting interpretations and explanations (see Ricoeur 1973:91-117). If historical events are texts, then any attempt to explain and understand them is primarily a hermeneutical task.

Events, like Marikana, are explained and understood once they are emplotted, that is to say, once they are integrated into a narrative that gives meaning to what happened. Ricoeur (1984) begins his three volume book, Time and narrative, with a short reflection on Augustine's struggle in Book 11 of Confessions with the concept of time. There is no phenomenology of time, as time 
as such does not exist. What does exist is the concept of time in everyday language. Augustine argues that we speak in categories of time all the time, but that of which we speak, does it actually exist? Is there time? No, there is no time and yet it exists in ordinary language, as it is a concept that is used to make sense of existence: our temporal existence. With the help of Aristotle, Ricoeur (1984) argues that time exists in narrative and it is through narrative that we make sense of our temporal experience.

Taking Ricoeur's thoughts into consideration, how can we explain and understand the event, Marikana?

As an event, it is something that happened in time, as one can place it within the month of August, the 16th, in the year 2012. One can even give the hours, that is, the duration of the event. Yet, such time qualifications do not help one in understanding or explaining the event. The event becomes understandable once it is placed into the context of what happened before and what happened after, once it is placed into the context of past-present-future. Ricoeur (1984:52) argues that the aporia of Augustine's interpretation of time is solved by making use of Aristotle's emplotment: muthos. Ricoeur (1984) argues:

emplotment is what qualifies an event as historical: the facts only exist in and through plots wherein they take on the relative importance that the human logic of the drama imposes on them. (p. 169)

For Ricoeur (1984:31ff.), as for Aristotle, this giving meaning to acts happens via the dual process of mimesis and muthos [emplotment]. Muthos is to compose, and more specifically it is the composing of plots (Ricoeur 1984:33). Mimesis is the active process of imitating or representing something (Ricoeur 1984:33). The various incidences of the 16th of August 2012, in the area of Marikana, through the dual operation of muthos and mimesis, have created (poiesis) the event: Marikana. Ricoeur develops these dual operations in his interpretation of Aristotle's Poetics (see Ricoeur 1984:31ff.).

Marikana is created (poiesis) by this dual operation and thereby re-presented, because the majority of those hearing or reading about the event were not physically present at Marikana on the 16th of August 2012. Such events are never only re-presented, as if it were possible to re-peat an event or to give a perfect replica of an event, but the event is revealed or unconcealed, in other words, communicated via muthos and mimesis, as it is placed within a certain plot that combines past-present-future into a coherent story that explains what happens and thereby offers an understanding of the event.

Can one speak of a true Marikana, of what really happened? In other words, a truthful account of what happened? Heidegger (1984) challenges us to think about what it means to argue for the truth of something.

The truth (aletheia) of Marikana is not about correctness, adequatio or exact correspondence between representation and what actually happened, because Marikana, as event, is unconcealed but always within concealment. In this understanding of truth, something is forgotten, namely, that before one can even ask questions of correspondence and correctness, one has to ask the question of what makes it possible to ask such questions. To ask if the report of Marikana, in for example the Sunday Times, got it right, is a secondary question. The primary question for Heidegger was: What makes it possible to ask questions concerning correct representations? Before the question of rightness or correctness can be asked, the event Marikana has to be unconcealed. It has to be made visible or revealed, and it is revealed within a Gesichtskreis, but this Gesichtskreis is not noticed, it is taken for granted and therefore remains concealed (see Meylahn 2013:40). This Gesichtskreis is the context or world or horizon in which events like Marikana are unconcealed: come to view.

Marikana is thus an Ereignis in Heidegger's terms. Albert Hofstadter, the translator of Heidegger's Poetry, language and thought, translates Ereignis as disclosure of appropriation (Hofstadter 1971:xxi). Marikana, as Ereignis, is the disclosing (unconcealing) of incidences, but seen together (emplotted) within or from a perspective of a specific Gesichtskreis (world of meaning), and it is only disclosed to the extent that it is appropriated into this world of meaning. Marikana is disclosed within and appropriated into a particular Gesichtskreis. This world of meaning is language as the house of being (see Heidegger 1971). Marikana is an Ereignis of or in language. Heidegger (1971:197) unpacks this idea, by arguing that poetry is the purest form of language. It is the purest form, because in poetry (poiesis) language gathers world and things together and thereby presences things within a world (Gesichtskreis), and it is in this world (Gesichtskreis) that things find their place. The Ereignis Marikana is disclosingly appropriated, in that the things (incidences) of that day are gathered together into a world where those gathered things make sense. Or the world (Gesichtskreis) creates the necessary space where the incidences of Marikana can be gathered together so as to disclose an event that can be appropriated and understood. The dif-ference (Austrag) 'disclosingly appropriates things into bearing a world as it disclosingly appropriates world into granting of things' (Heidegger 1971:202-203). An event (Ereignis), like Marikana, is created (poiesis) through language and is an event of language. The event, Marikana, cannot be presented (made present to one) but via poetics, and therefore it is an Ereignis of language.

Ricoeur (1984) develops Heidegger's thoughts, but focuses on Aristotle's muthos (emplotment) in his Poetics. The Ereignis Marikana is presented to one via emplotment (muthos), as the event is made or created (poiesis) coherent by being disclosed and appropriated within a story (plot) or Gesichtskreis (world). Taking Heidegger seriously, the incidences (things) as well as the Gesichtskreis (world) or the act and the plot are functions of language. Poetics is always a double-edged sword, or to use Derrida's (1981:99) term, a pharmakon, as language is always both remedy and poison, because in that 
it makes something present, it absents the 'actual event'. Or, as Ricoeur (1984:45) argues, 'Artisans who work with words produce not things but quasi-things; they invent the as-if'. Thus, he can also say: 'One makes a plot with what one knows, and a plot is by nature "mutilated knowledge"' (Ricoeur 1984:170).

Therefore there is no 'actual or real' event, because the only access to the so-called 'actual' event is through presentation via language and this present-making via language is poiesis: the invention of the 'as if'.

François Laruelle (1999) argues that there is only One. There is only language or text or poetics, therefore what is termed extra-linguistic, the so-called Other, does not really matter because the word 'Other' or 'extra-linguistic' is language, so that there is no Other beyond language. Thereby I am not saying that there is no reality, but what I am arguing, is that there is no reality outside of text. Or to use Derrida's (1997:158) phrase, there is no outside text.

Marikana, as Ereignis, is mediated via the dual process of mimesis and muthos. Ricoeur (1984:65) argues that plot mediates in at least three ways. It mediates between the individual incidents and the story taken as a whole. Plot brings to coherence the individual incidents that together make up the event as it draws a meaningful story from the diverse and even contradictory incidents. Secondly, plot also brings together factors as heterogeneous as agents, goals, means, interactions, circumstance, unexpected results (Ricoeur 1984:65). Lastly, plot mediates in that it brings the different modalities of time together into a coherent pastpresent-future (see Ricoeur 1984:66).

Marikana becomes an Ereignis, a moment of human history, only through this poetics, as mimesis and muthos, or in Heidegger's (1971) terms, through the Austrag of things carrying out world and world granting things a place. This is the way in which Marikana can be presented (made present) and thus re-presented. Thus, Marikana is a text, and in the context of the above it is justified to say, conscious that it might cause offence, that Marikana is a fiction (see Ricoeur 1984:64). In saying that it is a fiction, something virtual, I am in no way denying or downplaying the harsh and tragic 'reality' of the event.

There is no single Ereignis, Marikana, as there are different Marikanas, depending on how the different incidences are emplotted or how the different incidences (things) find a place in the world of the one narrating the story of Marikana, or of the one hearing or reading the story. One could use Ricoeur's three phases of the hermeneutical journey, pre-figuration (mimesis $\left.{ }_{1}\right)$, configuration $\left(\right.$ mimesis $\left._{2}\right)$, and re-figuration ( mimesis $_{3}$ ), not only with regard to reading and interpreting a text, but also with regard to the poiesis of a text like Marikana, and then subsequently again in reading the text. The news reporters, the political analysts, the historians and the archivists of South Africa poetically create (poiesis)
Marikana. Each of these created or fictional configurations is a mediation between their personal and ideological prefiguration and their desired or wished for re-figuration, in other words, how they expect their implied readers to accept and react to their specific configuration. The way in which Julius Malema, for example, configured Marikana was done with a very specific intention of how he desired the readers of his text to respond to the text. He had a certain re-figuration in mind in the hope that this re-figuration would maybe change the political landscape of South Africa. Although Julius Malema's configuration of Marikana had this blatant political agenda, all the configurations of Marikana have an agenda, although some are more subtle.

Everyone confronted with the Ereignis of Marikana is confronted with a disclosing appropriation, in other words a certain configuration. This disclosing appropriation happens within the context of Ricoeur's three phases. Marikana as text is already configured in a certain way. The configured text mediates between an implied pre-figuration (implied Gesichtskreis) and an implied re-figuration of how the text's configuration expects to be disclosed and appropriated by the implied reader. The configured text, Marikana, is not disclosed to the readers on a tabula rasa, but each reader has his or her own pre-figuration (Gesichtskreis) in which the configured text, Marikana, is disclosed and appropriated. No one is neutral with regards to Marikana, as the Ereignis has some or other impact on how life in South Africa is understood. The impact of such an Ereignis depends on many factors. It depends on a personal connection to Marikana, where family or friends are directly involved. Such personal connection will influence how the Ereignis is disclosed and how it is appropriated (explained and understood). With a little more distance, where the personal connection fades into the background, other aspects become important such as the impact of Marikana on the economic discourses of South Africa. Marikana, together with other industrial actions as well as the service delivery protests, have had an impact on the economic stability and on investor confidence in South Africa. This economic and more specifically investor economic discourse does not necessarily directly concern one, but indirectly it concerns all those who are connected and benefit from the global village, understood as an expression of the global financial markets. For the villagers $^{1}$ of the global village living in South Africa, Marikana influences the economic stability and investor confidence, which in turn influences the financial markets and by implication it influences the value of investments. Marikana also influences the marginalised (see Meylahn 2010:220ff.) with regard to job-security, fair wages, et cetera. Yet, this disclosure of Marikana is already an interpretation from an economic perspective or economic pre-configuration. It is a disclosure within an economic Gesichtskreis. The economic discourse is not a homogeneous discourse, but heterogeneous, depending on the economic ideology that the interpreter subscribes to. I mention this pre-configuration because economics is certainly a dominant discourse and thus a dominant narrative

1.For further exploration of the idea of being a villager in the Global Village see Meylahn (2010:220ff.) 
setting in which events are emplotted. There are numerous other possibilities, such as the judicial discourse trying to find out who is guilty with regard to the loss of lives. There is the political discourse and those seeking to score political points from such events and again there are different political discourses that offer opposing interpretations of such events.

Marikana can be disclosed and thus appropriated in numerous different ways depending on one's pre-figuration, the Gesichtskreis, in which it is disclosed and appropriated. This pre-figuration will influence how the configuration of the text is disclosed and consequently how the text is appropriated, how it is re-figured. Part of the re-figuration is how South Africa is viewed and what the future holds for those living in the re-figured South Africa after Ereignisse like Marikana.

These multiple possibilities of interpreting and understanding Marikana leaves the practical or public theologian with an ethical challenge. If all that public theologians have of Marikana are different configurations, dependent on the theologians' pre-figuration, as well as the theologians' desired re-figuration, together with the audience's pre-figuration and diverse re-figuring responses, how does one respond to an Ereignis like Marikana? For example, what norms could be used to interpret Marikana in an attempt to seek justice?

The moment one brings in the question of justice, the immediate question is: Whose justice?, which in turn depends on the different laws and the enforcement of these laws.

If justice is understood as the execution of the law, and the police have a duty to uphold the law, then in upholding the law they are justified to use force, and this legitimate violence is 'justified' as state-maintaining violence (see Benjamin 1996) in order to protect the interests of the state or status quo.

The strikers are justified, according to Benjamin's (1996) state-forming violence, by their desire to create a state where labour is paid a fair price. Where does Benjamin's third form of violence - divine violence - come in, which Žižek (2008:487f.) argues, is love?

The theologian, as Christian, is called to follow Christ and will be known as a follower of Christ through their love (Jn 13:35). This shift towards love is not an opting out with a sentimental interpretation of love (let us all love each other and then the challenges of Marikana will be solved). Rather, it is a movement towards understanding the church's (and theologian's) calling.

What is the calling of the church or practical theologian in this hermeneutic challenge? Is a practical theologian, as a public theologian, not called to help explain and interpret such events in the light of the gospel? Is this not the traditional role of practical theology, to interpret the context in the light ('normativity') of the gospel?
The church and theologians in the history of South Africa have done exactly that by placing certain historical-social Ereignisse in the light of a Text: the divine Metanarrative. For example, the theologians of the apartheid state interpreted certain Ereignisse within the metanarrative of God's special calling of the Afrikaner nation. A good example is how the Great Trek was emplotted together with the Battle of Blood River into a divinely ordained nationalist metanarrative. From the above it is clear that this is unavoidable, as Ereignisse are disclosingly appropriated via the mediation of a configuration (narrative) between pre-figuration and re-figuration. This is something that always happens, therefore one can argue that the liberation theologians did the same thing, just differently, and yet, both liberation and apartheid theologians will argue that their interpretation is true. This was Heidegger's (1984) argument, that truth (aletheia) is always an unconcealing within a concealing. One is convinced that a particular interpretation of events is a true presentation (correlation) of what actually happened, because one is unaware of the Gesichtskreis in which something is unconcealed, as the Gesichtskreis remains concealed. The Gesichtskreis remains concealed as it is my world, and as my world it is as obvious and as natural as the air I breathe, remaining totally unaware that this air that I am breathing, this Dasein, is not natural, but a social-historicalcultural construct. Therefore, differing perspectives can end in heated arguments, because alternative emplotments are not only different points of view, but they are different worlds, and as such, challenge each other. The other's world challenges the air I breathe (my Dasein). The 'New' South Africa, under the spiritual guidance of Archbishop Tutu, sought to re-figure a 'New' South African nation (Rainbow Nation) by emplotting the Ereignisse of the past into a new metanarrative of Truth and Reconciliation (Harris 2011).

Events are always emplotted within specific narratives that are embedded in particular discourses of power and that is a grammatological fact, but this leaves the practical or public theologian with a question: Are all these alternative emplotments equally valid? Is there a more just way of emplotting? Is there a way, to use Verne Harris's (2011:119) idea, to archive for justice?

With this call to archive for justice, what is the role of the church? What is the role of the postfoundational narrative practical theologian who cannot return to a modernistic foundational paradigm, but has to work in this textual space between texts and contexts? How to bring together text and context in this narrative approach, whilst archiving for justice? One can formulate this question differently: How to follow Christ into Marikana?

If Marikana is a text (fiction), then seeking and attempting to follow Christ's traces or footsteps into Marikana means to follow Christ into the textuality of Marikana. That means to seek and follow Christ in the three hermeneutical phases of mimesis. If the Christ narratives are part of the various theologians' narratives then these narratives form part of the treasure of narrative resources of the theologian's Christian 
pre-figuration. The idea or concept of a Christian is also a text and thus there are numerous configurations of what it means to be a Christian. Within the ecumenical movement it is impossible to establish a norm regarding what a Christian pre-figuration should look like. Yet, there are certain themes which, although they might not carry the same weight for all Christians, cannot be denied as being central themes within scripture, for example: love, justice and preferential option for the marginalised.

From a secular point of view, Jürgen Habermas (1979:2) tried to overcome the challenges of the relativity of perspectives by presenting universally acceptable validity claims, with which to argue that certain perspectives are better than others.

I would like to offer not Habermas's validity claims, but my own values, inspired by scripture, which can also be defended rationally in a postmodern, narrative and postfoundational context. In other words, if one agrees that one is living in a postfoundational context and that events are texts (Ereignisse), then one can agree to these values, which could then function as validity claims, arguing for the greater validity (not correctness) of certain interpretations over other interpretations.

Values such as:

- The value of justice, namely that one or more perspective and/or is always excluded and marginalised and this needs to be heard; thus the conviction that the conversation is never complete, but is always still to come. Here, justice is understood as giving place (presence) to that or those that do not have presence or place.

- The openness to the other, who is different and thus disrupts the totality of any interpretation (this includes the biblical other: widow, poor and orphan).

- The openness to listen to the other voices in interdisciplinary transversal dialogue.

- To not seek foundations, but to move beyond them towards postfoundational conversations.

- To value freedom and the possibility of the impossible, where dominant discourses are cracked open to make space for the previously impossible (see Meylahn 2012:13).

These values could pave the way for an ethical and responsible hermeneutic approach to configuring historical Ereignisse, as well as offering an ethical and thus responsible hermeneutic for reading these Ereignisse, which I believe is the calling of public theologians. These values accompany the public theologians as they follow Christ into Marikana.

The Christ narrative can be read as being exemplary of the story of language (see Meylahn 2013:310ff.). If the Christ narrative is interpreted as being exemplary of the story of language, then it can serve as a guiding narrative to interpret the world and various Ereignisse in the world. The narrative of Christ, as such a guiding narrative, provides the public theologian with a hermeneutic of the Christnarrative. Or a science of Christ, a Christołogy, but where the logos of Christology is erased like Heidegger's Being, but although erased still legible (see Derrida 1997:23). In other words, if anything it is a non-science science or nonphilosophy philosophy, because not to philosophise is still to philosophise. ${ }^{2}$

A Christology where the Logos, which became flesh, has been crucified (crossed out) by the dominant laws or discourses in the name of state-maintaining justice (see 1 Cor 2:8).

With this Christology, described in the narrative of Christ, and the values described above, the practical theologian is pre-figured to read or write the Ereignisse and thus facilitate a refiguring space within the public discourse. The configured text, as presented to the practical theologian and the public, is already configured by the newspapers and/or political analyst and/or the politicians and/or the archivist or the historian, et cetera.

These texts need to be doubly read - for what they say and what they do not say, as Critchley (1999:88ff.) argues for a clotural reading. In other words, the text is read to hear the dominant discourse with its ideological power motives, but then it is read again to hear the voice of those who are excluded by the dominant ideological configuration, thereby following Christ's incarnation amongst the least of the brothers and sisters, the marginal and excluded. The task of the practical theologian is not to offer an alternative ideological or religious configuration, as that would be futile, and only end in the battle of configurations, which is the case already. It is not the task of the practical public theologian to counter the capitalist reading of Marikana with a Marxist or liberation theological reading or writing of the text, but to identify the various dominant discourses that exclude within the different readings. The liberation discourse, as history has so often shown (see Žižek 2008:469), excludes as much as the capitalist discourse, as there is no real difference between state founding violence and state maintaining violence. What is needed is not an alternative configuration, but a deconstructive reading of the text through association with the marginal and excluded voices. Through these associations with the marginal and excluded, the dominant discourses are questioned and deconstructed. A deconstructive reading that is criminal and subversive is needed, because such kind of subversion or deconstruction can open texts to its other: the kingdom to come. What is needed is an ultimate criminal reading of the text that exposes the power and the violence of the various configurations or of any configuration. It is an ultimate criminality, as Benjamin's interpretation of the ultimate criminal (see Benjamin 1996), and thus a divine deconstructive violence, thereby revealing the truth of texts, namely that they are texts (fictions), and this truth will set free to embrace the coming of the kingdom that has already come in the cracks of the texts as impossible possibilities. This deconstructive reading that opens texts, is the hope and faith that inspires the practical theologian, exposing

2.'It was a Greek who said, "If one has to philosophize, one has to philosophize; if one does not have to philosophize, one still has to philosophize (to say it and think it)." One always has to philosophize' (Derrida 1978:152). 
the fictional character of all configuration of Ereignisse and thereby witnesses the rise of the mythological colourful phoenix from the ashes of deconstructed discourses. The task of the practical theologian is not to stand in judgment of the various configurations, but to move beyond judgment and thus categorisation into good and evil, towards love, and even love of enemies. Not loving the enemy out of arrogance of knowing better and therefore a condescending love, but in the weakness of realising all are texts - fragile clay jars. None have the truth, but for the gift of the impossible possibilities of the traces of God's presence (kingdom) placed within the clay jars (texts) and the privilege to witness these traces in faith and hope. The calling is to deconstruct the myths of Marikana, not in an attempt to arrive at the truth thereof, but, by exposing the myths, witness the possibility of a rising phoenix from the ashes. The rising phoenix is not the truth of Marikana, but is the impossible possibility of life after the crucifixion (divine violence) of the dominant discourses that hold our imaginations (re-figuration) captive.

Thereby, such a deconstructive reading opens a space for a colourful re-figuration of justice where the silenced voices are heard beyond the powerful discourses, and therefore a glimmer of hope beyond the finality and fatality of the dominant discourses.

\section{Conclusion}

From the above it is clear that such a Christo, as a hermeneutic for reading, is not a science, but if anything it is a nonphilosophy or a folly where one, as theologian, is inspired (in Spirited), in Levinas's (1981:142) terms, enucleated and held captive by the Other, which in essence is the description of the theologian as one who is overwhelmed by the Other, by the word of the Other (theo-logos): the thought of the Wholly Other who is every other (Derrida 1995:76). Or in Laruelle's (1999:143) terms, who is held captive and accountable only to the future (also see Alkon \& Gunjevic 2011:219).

This is of course folly and indeed maybe holy folly or the divine violence of exposing the power motives of all discourse, but without creating a new discourse that is right or good or morally superior to others and thus worthy to be followed, but truly offering only the deconstructed space, in the shadow of the cross, to God, without any works by which to justify our actions: soli deo Gloria. Offering the broken texts to God, as in the sacrament of the table, where the broken pieces of body or text are transformed into the presence of Christ through faith alone, as a gift of grace, in the hope of the impossible possibilities of the kingdom always still to come: The rising of the mythological phoenix, which has been used as a metaphor for the risen Christ, from the ashes of Marikana.

\section{Acknowledgements Competing interests}

The author declares that he has no financial or personal relationship(s) that may have inappropriately influenced him in writing this article.

\section{References}

Alkon, G. \& Gunjevic, B., 2011, 'According to the identity of the real: The nonphilosophical thought of immanence', Synthesis philosophica 51(1), 209-227.

Benjamin, W., 1996, 'Critique of violence', in P. Demetz (ed.), Reflections; essays, aphorisms, autobiographical writings, transl. E. Jephcott, pp. 277-301, Schocken, New York.

Critchley, S., 1999, The ethics of deconstruction: Derrida and Levinas, 2nd edn., Edinburgh University Press, Edinburgh.

Derrida, J., 1978, 'Violence and metaphysics: An essay on the thought of Emmanue Levinas', in J. Derrida, Writing and difference, transl. A. Bass, pp. 79-153, University of Chicago, Chicago.

Derrida, J., 1981, Dissemination, transl. B. Johnson, Continuum, New York.

Derrida, J., 1995, 'Sauf le nom', in J. Derrida \& T. Dutoit (eds.), On the name, transl. D. Wood, J.J. Leavey \& I. McLeod, pp. 35-88, Stanford University Press, Stanford.

Derrida, J., 1997, Of grammatology, transl. G.C. Spivak, John Hopkins Press, Baltimore. Habermas, J., 1979, Communication and the evolution of society, Beacon Press, Boston.

Harris, V., 2002, 'Contesting remembering and forgetting: The archive of South Africa's Truth and Reconciliation Commission', Innovation 24(June), 2-8.

Harris, V., 2011, 'Jacques Derrida meets Nelson Mandela: Archival ethics at the endgame', Archival Science 11, 113-124. http://dx.doi.org/10.1007/s10502-0109111-4

Heidegger, M., 1971, Poetry, language and thought, transl. A. Hofstadter, Harper \& Row, New York.

Heidegger, M., 1984, “Grundfragen der Philosophie: Ausgewählte "Probleme” der "Logik"', in V. Klostermann, Gesamtausgabe, B.45, Klostermann, Frankfurt.

Hofstadter, A., 1971, 'Introduction', in M. Heidegger, Poetry, language, thought, pp. ix-xxii, Harper \& Row, New York.

Laruelle, F., 1999, 'A summary of non-philosophy', Pli: The Warwick Journal of Philosophy 8, 138-148.

Levinas, E., 1981, Otherwise than being: Or beyond essence, transl. A. Lingis, Martinus Nijhoff, The Hague.

Meylahn, J-A., 2010, The Church in the postmodern global village: Towards pastoral redemptive communities, vol. 1, Lambert Academic Publishing, Saarbrücken.

Meylahn, J-A., 2012, Church emerging from the cracks: A church in, but not of the world, Sun Press, Bloemfontein.

Meylahn, J-A., 2013, The limits and possibilities of postmetaphysical God-talk: A conversation between Heidegger, Levinas and Derrida, Peeters Press, Leuven.

Ricoeur, P., 1973, 'The model of the text: Meaningful action considered as a text', New Literary History 5(1), 91-117.

Ricoeur, P., 1984, Time and narrative, vol. 1, transl. K. McLaughlin \& D. Pellauer, University of Chicago Press, Chicago. http://dx.doi.org/10.2307/468410

Žižek, S., 2008, In defense of lost causes, Verso, London. 